\title{
The Climate Change Crisis Demands Radical Change by All. How Must Structural Engineers Respond
}

\author{
Mohamed Elhassan \\ RIDA Group, Sudan
}

\section{INTRODUCTION}

The climate change, the global warming and their consequences are scientifically proven facts and a reality that communities should work together to address. The current warming trend is of an anthropogenic origin, and has been advancing since the mid20th century at an unprecedented rate. ${ }^{1}$ The compelling evidence of climate change is abundantly clear while continued development to support economic growth resulting from over-exploiting our planet resources. ${ }^{2}$ Seizing the evidence that climate science is indeed climate science, is the setting stone to respond to the climate change dilemma. It is in the in liability of us structural engineers- to acknowledge that we are part of the crisis, to advocate radical change in practices within the discipline and the built environment sector, and to initiate changes to policies in the construction industry, while joining a pledge to safe structural design, efficient materials use and design for performance.

\section{A CALL TO ACTION ON CLIMATE CHANGE}

\author{
"For us-engineers-we cannot get to a de-carbonized world \\ without leadership from the construction and the built \\ environment industry"-Keith Clarke, ICE UK. ${ }^{3}$
}

The quote from the vice president of the United Kingdom's Institution of Civil Engineers provokes two significant questions -what isn't being done? And what is required to be done, to address climate change? While the IPCC Fifth Assessment Report; namely "Climate Change 2014: Impacts, Adaptation and Vulnerability, Part A; Global and sectoral aspects" confirms that ,...adapting urban areas to climate change requires serious attention" 4 ; this gives clues on how to answer the first question, i.e. while engineers are adapting to climate change and increasing the resilience, they are only addressing the manifestation of the global crisis. Structural engineers should address the rudimentary reasons for climate change; a pledge to 'de-carbonization'. Modern structural engineers are expected to understand their part in the global climate crisis, and educate others about acquiring tools to remedy the harm and advocate for net zero-carbon commitment. They should raise climate awareness across team members, contractors, clients and policy makers, and crossshare data to benchmark progress against top efforts around the world. Setting priorities as building reuse and upgrading, material efficiency and design for performance not standards, are all part of an action plan that fulfils the needs of our society without damaging the planet's biodiversity.

\section{SUSTAINABLE STRUCTURAL DESIGN}

Peter Dunican, previous president of the IStructE, UK (1977-78), stated that "Structural engineering is not only concerned with the conception of structural system..., but it is equally concerned with service; service to the community, ensuring that our society is adequately informed about what we can do for it". Professional structural engineers have a position of trust in their communities, and with it come the responsibility towards society rather than shareholders; to be conscious of carbon footprints of their structural design decisions and reduce associated emissions, where design standards are change-makers. They are required to shift towards designing to code without over-capacity, and practicing performance-based design measure. Practical steps towards sustainable structural design include multiple pathways involving; 'Design for maximum utilization' where it is advised to avoid extra material, using only codes' safety factors, and design for reuse to promote zero waste during the structure's life-cycle. 'Design for zero-carbon energy' by using in-situ or local recycled materials; this reduce associated emissions of energy and transport and generate local income for smaller businesses.

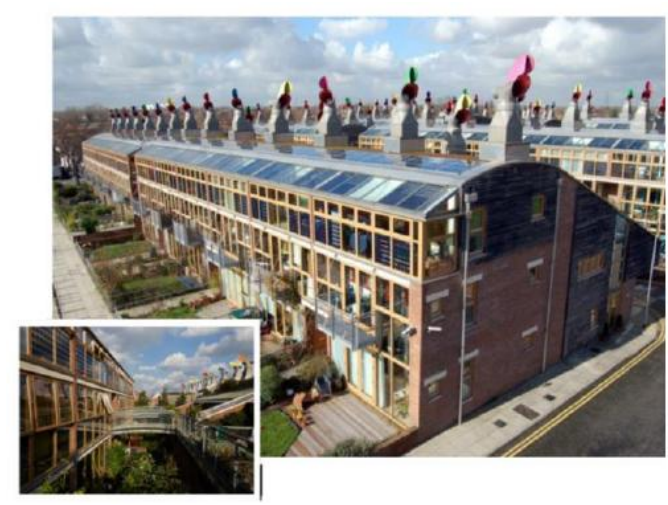

Figure 1: Bill Dunster Zedfactory Architects (BedZED), completed in 2002..$^{18}$ 
ISSN (online): 2581-3048

(Figure 1) illustrates the UK's first large scale, mixed-use sustainable community; with an estimated $\% 52$ of construction materials sourced within $56 \mathrm{~km}$ of the site and $\% 15$ recycled or reclaimed; 40 tons of structural steel reclaimed from a refurbishment project at Brighton railway station for the steel frame, and 1,000 tons of 'sand' made from crushed recycled glass was used under the outdoor paving slabs; BedZED is an inspiration for low-carbon housing developments. Other key corner-stones for sustainable design are designing for dualusage and flexibility, using in-situ waste and reducing landfill waste, and reducing transportation within- and outside the sites. The modern structural engineer should be able to utilize rational sustainability approaches to determine specific environmental impacts of a structure during its life cycle. He must incorporate technical experience and environmental awareness to effectively accord to a sustainable design team that can weave a cohesive design from contrasting requisites. Sustainable design integration provides a solid framework to address monotonous design stages. Although integrated design is not in its infancy, it is essential for a structural engineer to further adopt the concept of the holistic structure design and understand possible solutions during design discussions.

\section{STRUCTURAL MATERIALS CONTRIBUTION}

Structures are highly dependent on concrete and steel as primary structural materials, however; producing steel and cement amounts to \%10 of total GHG emissions, and neither materials are renewable. Although efficient processes are available, they are not able to significantly reduce carbon emissions, it is only possible to determine the volume of steel and cement produced annually, this is where structural engineers' role starts; they are responsible for determining how and where to use these materials.

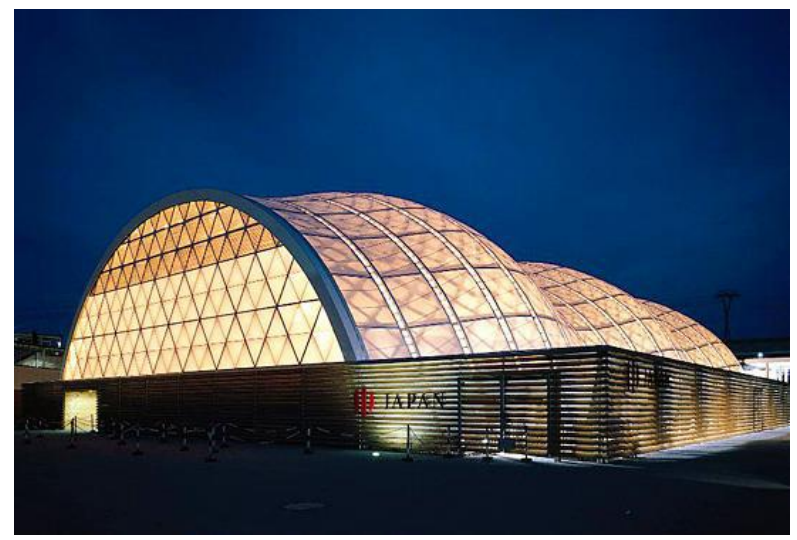

Figure 2: The Japanese Pavilion, Hannover Expo 2000. ${ }^{14}$

One of the most challenging tasks structural engineers face is assessing materials sustainability, due to the fact that sustainability is not an inherent property of a material. This places obstacles to explore alternative materials with lower environmental impacts. Timber and bamboo are renewables but release carbon when dying or land filling, while modern materials like fiber reinforced plastics can be commercially unavailable, uneconomic and polluting to produce. Shigeru Ban, the famous Japanese architecture, best demonstrated the use of pressed paper tubes as a structural system i.e. The Japanese Pavilion at the Hannover Expo in 2000 (Figure 2). While waiting for a material with huge benefits without significant problems, material efficiency is the 'answer'. Maximum material utilization, revising assumptions and reducing waste by customizing requisites to their use during design phase, in addition to selecting alternative measures such as off-site manufacturing, refurbish, reuse and resilience structure.

\section{DESIGNING OUT WASTE}

On September 2019, the Sustainable Development Solutions Network (SDSN) published 'A Roadmap to 2050: A Manual for Nations to Decarbonize by Mid-Century' jointly with Fondazione Eni Enrico Mattei (FEEM). One of the main pillars to achieve zero-net emissions by 2050 is Materials Efficiency via the introduction of circular economy and waste management systems as national actions. Designing out waste is one of the key presumptions of circular economy (Figure 3), that depicts the flow of resources in nature. Modern structural engineers need to realize effective communications with design team and clients to incorporate circular economy into developing business models and sustainable designs, while consequently lacking relevant expertise, metrics and technological solutions.

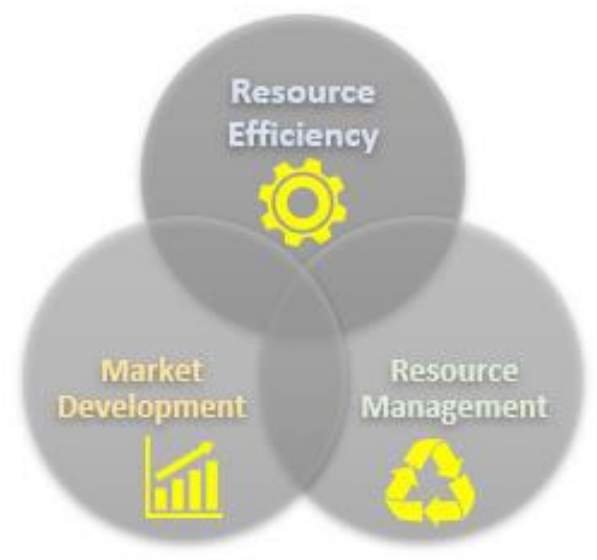

Figure 3: Zero-Waste Circular Economy; an economic, environmental and moral necessity by Scottish Government. ${ }^{15}$

While the construction waste accounts for a 3rd of waste generated in the European Union alone, it has a huge potential for circular economy mediation. Meanwhile, practical measures to reduce waste in design, enhancing materials service and designing for resource efficiency is a must for the 
ISSN (online): 2581-3048

Volume 5, Issue 12, pp 87-90, December-2021

https://doi.org/10.47001/IRJIET/2021.512017

construction sector. During design, decreasing load values, deflection limits and partial factors can significantly reduce materials used. It has been indicated that full utilization in each member can result in \% 30 less material in structures, while this is in the control of the structural engineer to apply best practices, it is for the contractors to logically optimize the design for their benefit. Opportunities to remove material can arise by optimizing the geometry or varying the section. All these practices cannot be made without involving clients and contractors. ${ }^{19}$ Waste minimization in structural design was previously a response to legislation and rapid rise of landfill costs. Therefore, when materials are averted from landfills, their value cheapens which prevents them from being reintroduced into the cycle. With resource scarcity being a threatening issue for the construction industry, preventing waste at source, reusing and recovering as -added valueemergent responses from structural engineers is a must; towards 'sustainable design'.

\section{INFRASTRUCTURE}

Climate change threatens physical infrastructure both private and public; including schools, hospitals, residential buildings, public facilities, roads, dams and bridges. These infrastructures are often located in cities that represent centers of development due to higher densities. Therefore; cities are ideally placed to test climate adaptation and mitigation solutions. In November 2009, El Salvador experienced extreme rainfall over the course of two days which caused severe flooding and landslides in seven of the country's 14 departments, including San Salvador. Damage to infrastructure included 43 destroyed bridges and 171 damaged ones. The country sought international policy capacity building assistance. Climate resilient processes included selection of structural mitigation measures from flood levees, ocean wave barriers to evacuation shelters. These efforts resulted in increased mitigative capacity. Therefore, it is highly rudimentary for the structural society to pledge in a Hippocratic oath to remain committed to safe, reliable and sustainable structural design and attention to structures and infrastructure they create. ${ }^{19}$

\section{REFERENCES}

[1] United Nations Development Programme (2011). Paving the Way for Climate-Resilient Infrastructure: Guidance for Practitioners and Planners. New York, New York: United Nations Development Programme.

[2] Jackson, R. (2020). The Effects of Climate Change. [online] Climate Change: Vital Signs of the Planet. Available at: https://climate.nasa.gov/effects/ [Accessed 25 Jan. 2020].
[3] Anon, (2020). [online] Available at: https://www.enr.com/articles/48389-a-call-to-actionforengineers-on-climate-change [Accessed 26 Jan. 2020].

[4] IPCC, 2014: Climate Change 2014: Synthesis Report. Contribution of Working Groups I, II and III to the Fifth Assessment Report of the Intergovernmental Panel on Climate Change [Core Writing Team, R.K. Pachauri and L.A. Meyer (eds.)]. IPCC, Geneva, Switzerland, $151 \mathrm{pp}$.

[5] Stewart, M. and Deng, X. (2015). Climate Impact Risks and Climate Adaptation Engineering for Built Infrastructure. ASCE-ASME Journal of Risk and Uncertainty in Engineering Systems, Part A: Civil Engineering, 1(1), p.04014001.

[6] Megan Stringer, L. and Mark D. Webster, L. (2020). STRUCTURE magazine | Structural Engineers and Climate Change. [online] Structuremag.org. Available at: https://www.structuremag.org/?p=12613 [Accessed 26 Jan. 2020].

[7] Sustainability Guidelines for The Structural Engineer. (2010). Reston, Virginia: The American Society of Civil Engineers, pp.1-47, 146-250.

[8] Webster, M. (2004). Relevance of Structural Engineers to Sustainable Design of Buildings. Structural Engineering International, 14(3), pp.181-185.

[9] Ochsendorf, J. (2004). Sustainable Structural Design: Lessons from History. Structural Engineering International, 14(3), pp.192-194.

[10] Internal Market, Industry, Entrepreneurship and SMEs - European Commission. (2020). Circular economy Internal Market, Industry, Entrepreneurship and SMEs - European Commission. [online] Available at: https://ec.europa.eu/growth/industry/sustainability/circ ular-economy_en [Accessed 27 Jan. 2020].

[11] Resourceefficientscotland.com. (2020). [online] Available at: https://www.resourceefficientscotland.com/sites/default /files/Designing\%200ut\%20Construction\%20Waste\% 20Guide_0.pdf [Accessed 20 Jan. 2020].

[12] Unccelearn.org. (2020). Cities and Climate Change. [online] Available at: https://unccelearn.org/course/view.php?id=21\&page $=$ c ourse [Accessed 19 Jan. 2020].

[13] Huffpost.com. (2020). HuffPost is now a part of Verizon Media. [online] Available at: https://www.huffpost.com/entry/now-is-the-time-toact-on_b_5738574?utm_hp_ref=tw [Accessed 30 Jan. 2020].

[14] WikiArquitectura. (2020). Japan Pavillion Expo 2000 Hannover - Data, Photos \& Plans - WikiArquitectura. [online]

Available

at: 
ISSN (online): 2581-3048

Volume 5, Issue 12, pp 87-90, December-2021

https://doi.org/10.47001/IRJIET/2021.512017

https://en.wikiarquitectura.com/building/japanpavillionexpo-2000-hannover/\#expo-2000-pabellonjapones-13 [Accessed 30 Jan. 2020].

[15] Gov.scot. (2020). Making Things Last: a circular economy strategy for Scotland - gov.scot. [online] Available at: https://www.gov.scot/publications/making-things-lastcircular-economy-strategyscotland/ [Accessed 30 Jan. 2020].

[16] World Green Building Council. (2020). New report: the building and construction sector can reach net zero carbon emissions by 2050 | World Green Building Council. [online] Available at: https://www.worldgbc.org/news-media/WorldGBCembodied-carbon-report-published [Accessed 30 Jan. 2020].
[17] Abraham, J. (2020). Global climate projections help civil engineers plan | John Abraham. [online] the Guardian. Available at: https://www.theguardian.com/environment/climateconsensus-97-per-cent/2017/may/25/global-climateprojections-help-civil-engineers-plan [Accessed 30 Jan. 2020].

[18] Openhouselondon.open-city.org.uk. (2020). BedZED | Open House London 2019. [online] Available at: https://openhouselondon.open-city.org.uk/listings/1594 [Accessed 31 Jan. 2020].

[19] Istructe.org. (2020). The Institution of Structural Engineers - IStructE. [online] Available at: https://www.istructe.org/ [Accessed 31 Jan. 2020].

\section{Citation of this Article:}

Mohamed Elhassan, "The Climate Change Crisis Demands Radical Change by All. How Must Structural Engineers Respond" Published in International Research Journal of Innovations in Engineering and Technology - IRJIET, Volume 5, Issue 12, pp 87-90, December 2021. Article DOI https://doi.org/10.47001/IRJIET/2021.512017 